\title{
The Line-Type Optimization of Horizontal Arch-Ring for Floating Arch Cofferdam
}

\author{
Zhen Wang ${ }^{1,2^{*}}$ and Zhibin Liu $^{3}$ \\ ${ }^{1}$ School of economic and management, North China Electric Power University, Beijing, China \\ ${ }^{2}$ Schoole of civil engineering and hydraulic engineering, Ningxia University, Ningxia, China \\ ${ }^{3}$ China Institute of Water Resources and Hydropower Research, Beijing, China \\ ${ }^{*}$ Corresponding author
}

\begin{abstract}
The study proposes the optimized line-type of a reusable floating arch cofferdam creating the dry area to reinforce the dangerous dam. The water is discharged from the cavity of the arch cofferdam which automatically rises in the water, and then pulls to the next construction site. So the linetype of floating arch cofferdam need optimize in order to reduce the engineering quantity but enough strength. The study estimates the force performance, the deformation at the support and the engineering quantity of five schemes using CAD and SAP software. The schemes respectively are the semi-circle, single center circle that the center angle is $140^{\circ}$, elliptical arch, and two three-center's circle. The final conclusion is that the semi-circle is preferred for surrounding a dam section, and the three-center circle $\left(60^{\circ}\right)$ is preferred for surrounding more than two dam section. The floating cofferdam has practical application value, and the structure of the floating arch cofferdam is innovative.
\end{abstract}

Keywords-floating cofferdam; arch; line-type; CAD; SAP finite element analysis software

\section{INTRODUCTION}

Some aging dam can not operate regularly in China owing to backward construction technology and poor quality in early stage, Such as Feng Man dam. The concrete gravity dam is located in the southeast of the city of Jilin on the Songhua River, which was built in 1937 and the concrete pouring amount of the dam was about $89 \%$ before 1949 . Later Feng Man dam is to be continued construction on a large scale and renovates due to historical reasons. Finally the dam was built completely in 1953 . The dam's length and height is $1080 \mathrm{~m}$ by $93 \mathrm{~m}$, which is divided into 60section,Each section's length is $18 \mathrm{~m}$ and consists of retaining dam section, dam section, and overflow dam. The dam has withstood the test of the highest flood level of $266.18 \mathrm{~m}$ in 1957 and the lowest level of $225.1 \mathrm{~m}$ in 1990 . The dam has already run for more than 60years and undergone multiple maintenance and reinforcement. So far many defects and problems have existed[1-4]: (1) poor quality and weak concrete in dam body, (2) large faults and fractured zones in the dam foundation, (3) poor anti- seepage performance, (4) Insufficient flood control capacity, (5) poor seismic resistance.

The above mentioned problems have been pointed out by East Department of science and Technology of Northeast Electric Power Group Co., Ltd in" Notice of the expert argumentation on the research of the construction scheme of the water in the Feng Man power plant". In order to solve the Feng Man dam reinforcement, Wang et al.[5] proposes floating arch cofferdam and analyzes the semi-circle' cofferdam for Feng Man dam. First, the cofferdam surrounds one or two dam section, which creates a "dry operating environment", and then the upstream face of the dam can be reinforced. After that the water is discharged from the cavity of the arch cofferdam, which automatically rises in the water and pulls to the next construction site. Finally the cofferdam is filled with water again butting connection and sealing water, and then is drained water in the surrounding space in order to create another dry operation environment for reinforcing dam. So the arch cofferdam is easy to improve the construction condition and the construction of the dam reinforcement in the whole year is possible. If a number of floating arch cofferdams construct at the same time, the construction progress can be accelerated. The design schemes of the study need reduce the water level of the reservoir and minimize the impact of the social economy as much as possible. So we need consider the size of the construction working area, the floating arch cofferdam length, and its stress etc.

We collect the relevant literatures of cofferdams at present. Then the three indexes of five schemes for the floating cofferdam are analyzed by CAD and SAP software, including the engineering quantity, the stress and the deformation. Finally, the optimal schemes of the floating arch cofferdam are presented.

\section{LITERATURE}

At present, there are several kinds of reinforcement schemes for the Feng Man dam[6], such as upstream impervious reinforcement scheme, curtain grouting reinforcement scheme, concrete core wall reinforcement scheme. But in any one of the above reinforcement scheme dry construction working area cannot be created so that the dam reinforces with difficulty. That is to say, the implementation of these schemes must close the hydropower units, which affects the normal power generation. But the floating cofferdam creates dry working area, which neither affects the work of the unit nor impedes the flow of water.

Some engineering cases ever repair the upstream face of the dam by the cofferdam creating dry construction environment. It mainly has the following [7]: Mactaquac Hydropower Station of Canada, Joseph dam heightening project of America, and Okutadami Hydropower Station of Japan. Mactaquac station only creates a dry environment to facilitate construction, but the length of the dam is not large, the cofferdam is only used 
once. The floating cofferdam of Joseph by sealing spillway orifice reconstructs the pier and does not lower the reservoir level. The reinforcement of joseph dam is the part dam rather than the whole dam. Steel cofferdam of Okutadami is used only once for the summer construction. $\mathrm{Li}[8]$ discusses the anti-ship collision suspended steel cofferdam in Shanghai Changjiang River Bridge and analyzes the deformation and strain state under the stage of construction and floating-transportation by the finite element method. Rajasekhar[9] designs a suitable water-tight chamber and uses it as a cofferdam to renew the shell plate. Quaglia[10] evaluates the construction of a cellular cofferdam in Puerto Belgrano Naval Base as a series of changes in site conditions and constructions deviations. Zhu[11] gives a model for complete resistance calculation and stability analysis of floating steel cofferdam in order to raise the load capacity of the bridge pier foundation. Travers[12] designs the cofferdams' retaining walls in a dock environment. The cofferdam mentioned in the literature is only used for the local of the structure, but the length of Fengman dam is larger, and the design and construction of the cofferdam is more complex. In this paper, the cofferdam's line-type of Fengman dam is discussed and compared the deformation and the stress of the floating cofferdam's five schemes.

In summary, in order to reinforce the fullness upstream surface of the dam, a new type of cofferdam is presented[5] which encircles one or two dam sections, creating dry working area for the construction. Until the reinforcement completion of the dam, the floating arch cofferdam transfers to another place by the buoyancy balance method. The cofferdam can be used repeatedly for many times. Wang[5] designs and analyzes the semi-circle type of the floating cofferdam, Zhao[13] presents the technology of the floating semi-circle arch cofferdam and its experiment. Thus we optimize the floating arch cofferdam schemes of horizontal arch type, especially for single center circle that the center angle is $140^{\circ}$, elliptical arc and three center's circle, comparing with semi-circle type of the floating arch cofferdam.

\section{LINE-TYPE OPTIMIZATION}

\section{A. Analysis Based on the Semi-circle Arch-ring}

The center angle and radius of horizontal arch type are the important parameters of the arch cofferdam, which determine each layer arch contour. Choosing the center angle and radius, we must consider the engineering quantity of the arch cofferdam, the stress of arch structure, and the deformation under water pressure. Figure 1 shows the horizontal arch. Under uniform water pressure $\mathrm{P}$ is along the outer arch. According to the static equilibrium condition, it can be concluded as:

$$
\begin{aligned}
T & =\frac{2 l p}{(2 \sigma-p) \sin \varphi_{A}} \\
\sigma & =\frac{l p}{T \sin \phi_{A}}+\frac{p}{2}
\end{aligned}
$$

$\mathrm{T}$ is defined as the thickness of the arch ring; is the average stress of the section of the arch;

$$
l=\frac{R}{2 \sin \phi_{A}}
$$

1 is the average radius of the semi-arch chord, $\varphi \mathrm{A}$ is $1 / 2$ angle, $R$ is the average radius.

The engineering quantity do not just consider the material amount used in the construction of arch cofferdam but the drainage quantity of the dry working area of the arch cofferdam.

For the semi-circle, the volume of the unit height of thick arch $\mathrm{V}$ (Considering the arc length) as:

$$
V=2 \phi_{A} \cdot R \cdot T
$$

The enclosed area of the arc cofferdam Aw can be calculated according to equation (5):

$$
A_{w}=\phi_{A}(R-T / 2)^{2}
$$

Equation (5) shows the volume $\mathrm{V}$ and the area Aw which increases linearly with the increase of $\varphi \mathrm{A}$.

From the above analysis can be seen, the engineering quantity increases with the arch of the increasing central angle, but the section stress of arch abutment decreases for the single center circle shape. Therefore the force performance and the engineering quantity are contradictory. The above issues should be considered and the line-type of the arch cofferdam is optimized as following by CAD. The five schemes are screened and evaluated, which are respectively the shape of semi-circle, single center circle that the center angle is $140^{\circ}$, elliptical arch and two three-center's circle.

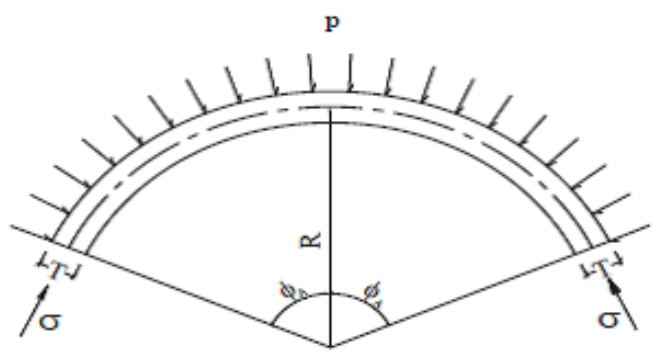

FIGURE I. THICK CIRCULAR ARCH COFFERDAM

\section{B. Discussion}

Based on the reinforcement of two section dam, we analyze the engineering quantities and the force performance of the various line-types of the arch cofferdam assuming that $8 \mathrm{~m}$ width of the work area. Namely $36 \mathrm{~m}$ x $8 \mathrm{~m}$ rectangular space should be given in the plane of the cofferdam. For comparison, the arch thickness of the cofferdam $\mathrm{T}$ is $4 \mathrm{~m}$ using the box section (Figure 2). The thickness of section shell is $200 \mathrm{~mm}$.Each schemes' plain layout is shown in figure2-6. 


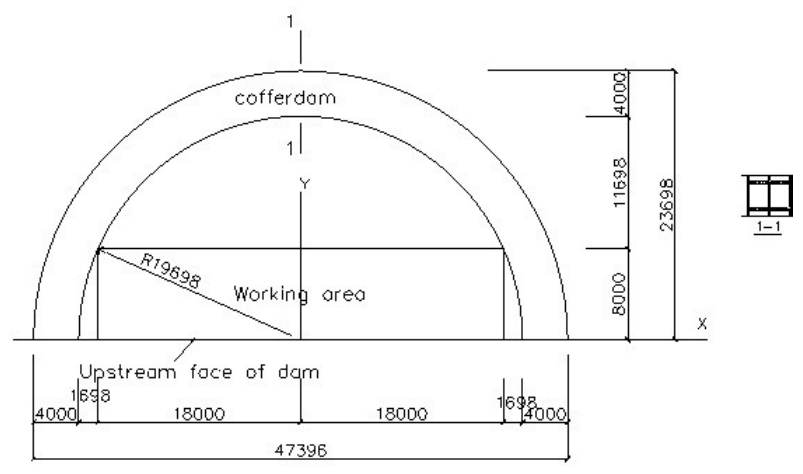

FIGURE II. SEMI-CIRCLE (180) AND BOX SECTION OF PLAN1

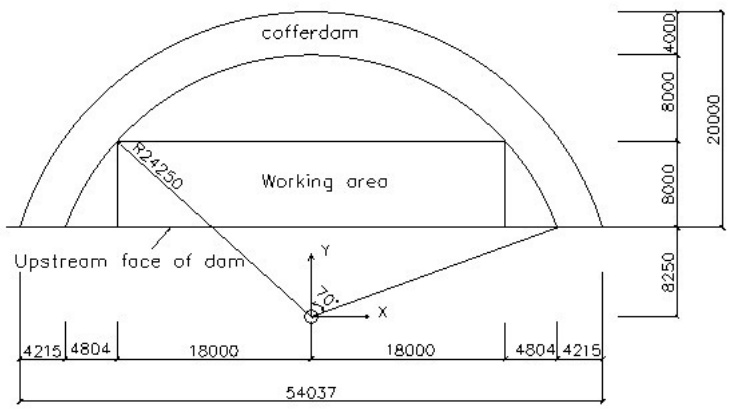

FIGURE III. SINGLE CENTER CIRCLE ( $\left.140^{\circ}\right)$--PLAN 2

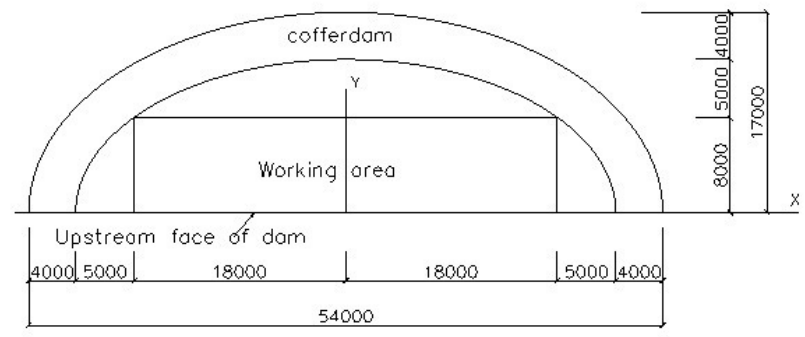

FIGURE IV. ELLIPTICAL ARCH--PLAN 3

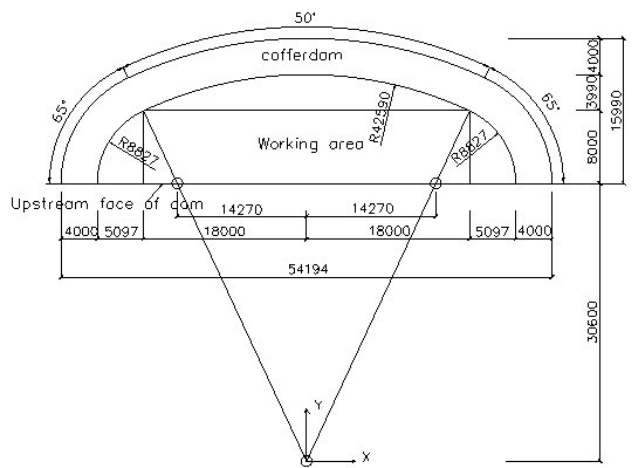

FIGURE V. THREE-CENTER'S CIRCLE(50) --PLAN 4

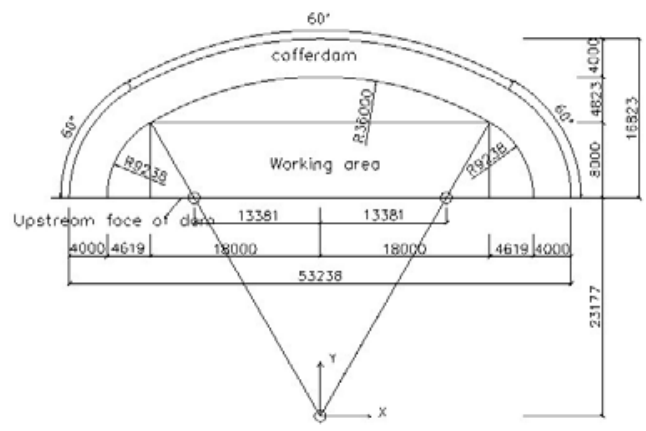

FIGURE VI. THREE-CENTER'S CIRCLE $\left(60^{\circ}\right)$--PLAN 4

Table 1 lists the engineering quantities of each scheme. From the table1 can be seen, The center angle is the largest, and also the engineering quantity of the scheme 1 is the largest. Compared with scheme 1 , the degree of reduction has different for the others' engineering quantity. Among them, reduction of scheme 4 is the largest, the amount of cofferdam's material decreases by about $6.1 \%$, the displacement decreases by $27.3 \%$. For scheme 4, the amount of material decreases by about $7.1 \%$, the displacement decreases by $25 \%$.

TABLE I. COMPARISON OF THE ENGINEERING QUANTITIES OF VARIOUS PLANS

\begin{tabular}{|c|c|c|c|c|c|}
\hline $\begin{array}{c}\text { Comparison of the } \\
\text { plans }\end{array}$ & Plan1 & Plan2 & Plan3 & Plan 4 & Plan5 \\
\hline $\begin{array}{c}\text { Cofferdam } \\
\text { horizontal area } \\
\mathrm{A}\left(\mathrm{m}^{2}\right)\end{array}$ & 272.662 & 262.772 & 254.206 & 228.68 & 253.321 \\
\hline $\begin{array}{c}\text { Enclosed area of } \\
\text { cofferdam Aw }\left(\mathrm{m}^{2}\right)\end{array}$ & 609.469 & 531.460 & 462.714 & 442.862 & 457.432 \\
\hline
\end{tabular}

\section{RESUlTS}

Using SAP finite element analysis software, the above five schemes are respectively modeled and calculated. The study analyzes an arch ring bearing the external water pressure $50 \mathrm{~m}$. Only the direction of $\mathrm{Y}, \mathrm{Z}$ is constrained, and the direction of $\mathrm{X}$ is not bound (along the direction of the dam) at the support. Table 2 lists the inner force and the deformation of the schemes.

TABLE II. COMPARISON MAXIMUM VALUE OF THE INNER FORCE AND THE DEFORMATION OF THE SCHEMES

\begin{tabular}{|c|c|c|c|c|c|}
\hline $\begin{array}{c}\text { Inner force and } \\
\text { deformation }\end{array}$ & $\begin{array}{c}\text { Plan } \\
\mathbf{1}\end{array}$ & $\begin{array}{c}\text { Plan } \\
\mathbf{2}\end{array}$ & $\begin{array}{c}\text { Plan } \\
\mathbf{3}\end{array}$ & $\begin{array}{c}\text { Plan } \\
\mathbf{4}\end{array}$ & $\begin{array}{c}\text { Plan } \\
\mathbf{5}\end{array}$ \\
\hline $\begin{array}{c}\text { Bending moment } \\
(\mathrm{kN} \cdot \mathrm{m})\end{array}$ & 0 & 142457 & 268884 & 133134 & 87689 \\
\hline $\begin{array}{c}\text { Circumferential } \\
\text { tension stress } \\
(\mathrm{Mpa})\end{array}$ & 0 & 52.47 & 106.2 & 46.56 & 19.02 \\
\hline $\begin{array}{c}\text { Circumferential } \\
\text { pressure stress } \\
(\mathrm{Mpa})\end{array}$ & -13.02 & -69.60 & -124.20 & -67.52 & - \\
\hline $\begin{array}{c}\text { Deformation at } \\
\text { the support (mm) }\end{array}$ & 7 & 136 & 307 & 159 & 31 \\
\hline
\end{tabular}

By the data in Table 2, the working performance of the scheme 1 is the best, both the inner force and the deformation are optimal. In the case of bearing the hydrostatic pressure, the tension stress and bending moment are 0 for scheme 1 , and the average pressure stress is the least. In the other four schemes, the working performance of scheme 5 is better, which is 
followed by scheme 4 and 2, the working performance of scheme 3 is worst.

From the above analysis can be seen, the engineering quantity of scheme 1 increases due to reinforce two dam section which is emboweled the dry working area of $36 \mathrm{~m} * 8 \mathrm{~m}$ by arch cofferdam, but from the point of the working performance, scheme 1 is best. Therefore, only if reinforcing a dam section $(18 \mathrm{~m} * 8 \mathrm{~m}$ work area), scheme1should have priority to be screened. while reinforcing two or more than two dam section, scheme 5 should be screened. The defects of the working performance of scheme 5 can be solved by using the external pre-stressing technology.

\section{CONCLUSION}

The study presents the optimized line-type of the concrete floating arch cofferdam which ensures the dry construction condition to reinforce the dam, so as to avoid the serious economic loss emptying reservoir and a series of social and environmental problems. This study mainly analyzes the engineering quantity, the working performance and the deformation of five schemes of the floating arch cofferdam. The conclusions are drawn as follows: First, the semi-circle is preferred for $18 \mathrm{~m}$ dam section, because the bending moment and the stress is zero, the deformation is the smallest, the working area is small and the engineering increment is not large. Secondly, In comparison to other schemes, the working performance, the deformation and the engineering quantity of the three center circle $\left(60^{\circ}\right)$ are smaller. So the three center circle $\left(60^{\circ}\right)$ is preferred for more than $18 \mathrm{~m}$ dam section.

The process of dam reinforcement, the floating arch cofferdam has the following superiority:(1)Do not affect the normal operation of hydropower station;(2) Do not affect the safety and stability of the dam;(3) Maintain the ability to release flood waters of the dam under any circumstances. Therefore, the schemes have practical application value, and the structure of the floating arch cofferdam is innovative. Research results can be widely used in the reinforcement and restoration projects of large dams, which can bring significant economic and social benefits.

\section{REFERENCES}

[1] IWHR, "Basic Case and Seepage Control of Upstream Face Less than 226m in the Fengman Dam", F.p.p. infrastructure, Editor, 1994.

[2] IWHR, "The Long-Term Safety Evaluation Report for Fengman Dam", C.N.C.o.L. Dams., Editor, 2006.

[3] IWHR, "Feasibility Study on Comprehensive Management Scheme of the Fengman Dam - Project Engineering Investigation, Investigation and Literature Retrieval Report", C.N.C.o.L. Dams., Editor, 2006.

[4] IWHR, "Fengman Dam Long-Term Safety Evaluation of Special Evaluation", C.N.C.o.L. Dams., Editor, 2006.

[5] Zhen Wang, H.L., Zhibin Liu,Chenguang Li, "Design an Analysis of the Floating Arch Cofferdam". Building Technique Development[J], (02): p. 1-3,2008.

[6] Yan, G. and X. Ren, "Study on Seepage Prevention Reinforcement Scheme of the Fengman Dam". water conservancy and hydropower school of Jilin [J],2004

[7] D.G.Hayward, "Repair Measures of Mactaquac Power Station, Aging and Repairing Measures of Dam, the Seventeenth International Conference on Dam", S.s.o.m.o.p.i.a.p.c. department, 1993.

[8] Li, W., Z. Feng, Z. Hu, D. Xun, J. Zeng, and Q. Peng, "Key Design and Construction Techniques for Collisionproof Steel Cofferdam for Large
Span Cable-stayed Bridge". Innovation in Civil Engineering, Architecture and Sustainable Infrastructure[J].Vol 238: p. 677-683,2012.

[9] Rajasekhar, D., N. Ravi, A.K. Rao, and D. Narendrakumar, "A Finite Element Approach to Renew Underwater Shell Plate of a Dumb Barge Sans Dry Docking: an Innovative and Cost-Effective Model". Ships and Offshore Structures[J].Vol 7(2): p. 215-222,2012.

[10] Quaglia, G., "Case History: Challenges During the Design and Construction of a Cellular Cofferdam", Y.J. Cui, et al., Editors. p. 568$571,2013$.

[11] Zhu, H. and X. Zhang, Floating Stability Analysis of Steel Boxed Cofferdam of Dongtinghu Long-Span Bridge, in Advanced Materials and Processes Iii, Pts 1 and 2, S. Li, W. Li, and J. Li, Editors. 2013. p. 897-900.

[12] Travers, R. and H.-C. Yeow, "Canary Wharf Crossrail Station Cofferdam, London, UK: Design, Construction and Performance". Proceedings of the Institution of Civil Engineers-Geotechnical Engineering[J].Vol 167(2): p. 169-181,2014.

[13] Zhao, Y., F. Chai, Y. Sun, R. Wang, Z. Liu, and Z. Bao, "Technology of Floating Arch Cofferdam and its Experiment Research". Journal of Hydraulic Engineering[J].Vol 45: p. 157-159,2014. 